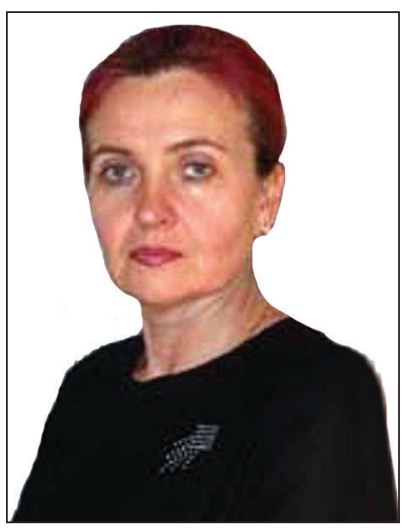

Denisenko Marina Aleksandrovna, PhD in Law, Associate Professor, Associate Professor of the Department of International Private and European Law, Belarusian State University, Republic of Belarus, Minsk. e-mail:marina-denisenko@tut.by

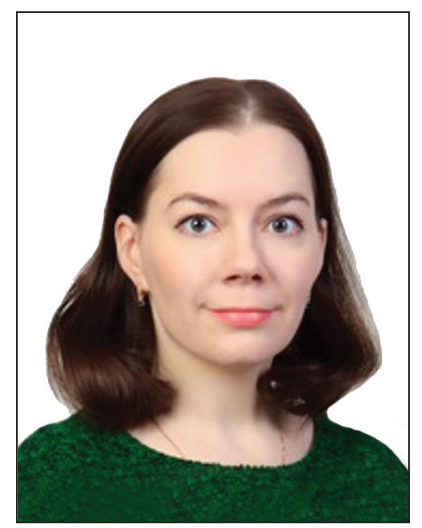

Maskaeva Natal'ja Gennad'evna, PhD in Law, Associate Professor, Associate Professor of the Department of International Private and European Law, Belarusian State University, Republic of Belarus, Minsk. e-mail:maskayeva_nat@mail.ru

\title{
CIVIL LAW PROTECTION FROM DIRECT DISCREDITING: THE PARIS CONVENTION AND THE BELARUSIAN LEGISATION
}

The article analyzes the provisions of the Paris Convention for the Protection of Industrial Property of 1883 and the legislation of the Republic of Belarus concerning unfair competition through direct discrediting. The civil remedies and liability that can be applied in case of the commission of the relevant offense are considered in detail. It is concluded that the Republic of Belarus fully abides by its relevant international obligations undertaken under the Paris Convention and that there is a number of gaps in Belarusian legislation, which negate the feasibility of the recourse for judicial protection in case of direct discrediting. Certain legislative amendments are proposed as well.

Keywords: business reputation; discrediting; competitor; unfair competition; denigrating information 
Денисенко М. О., кандидат юридичних наук, доцент, доцент кафедри міжнародного приватного та європейського права, Білоруський державний університет, Республіка Білорусь, м. Мінськ.

e-mail: marina-denisenko@tut.by

Маскаєва $\boldsymbol{H}$. $\boldsymbol{\Gamma}$., кандидат юридичних наук, доцент, доцент кафедри міжнародного приватного та європейського права, Білоруський державний університет, Республіка Білорусь, м. Мінськ.

e-mail: maskayeva_nat@mail.ru

Цивільно-правовий захист від прямої дискредитації: Паризька конвенція і білоруське
законодавство
У статті аналізуються положення Паризької конвениї щодо охорони промислової власності 1883 р. і законодавства Республіки Білорусь, які стосуються недобросовісної конкуренцї шляхом прямої дискредитаиії (далі - пряма дискредитаиія). Розглянуто суб'єкти, об'єкти, способи дискредитації, співвідношення поняття недобросовісної конкуренції, закріпленого в абз. $10 \mathrm{~cm} .1$ Закону Республіки Білорусь від 12 грудня 2013 р. «Про протидію монополістичної діяльності і розвиток конкуренцї», $і$ ї форм, передбачених у статтях 25-30 цього Закону. Висвітлено питання осудності справ, пов'язаних із здійсненням недобросовісної конкуренції, особливості прямої дискредитаиї на відміну від інших форм недобросовісної конкурениії, співвідношення недобросовісної конкуренцї і реклами, заходи цивільно-правового захисту і відповідальності, які можуть бути застосовані у разі здійснення вказаного правопорушення. Особливу увагу приділено аналізу постанови пленуму Вищого господарського суду Республіки Білорусь від 26.04.2005 p. № 16 «Про деякі питання застосування судами законодавства при розгляді справ про захист ділової репутації» $у$ зв'язку з можливістю його застосування за аналогією в тому ж обсязі. За результатами проведеного дослідження зроблено висновок про дотримання Республікою Білорусь повною мірою відповідних міжнародних зобов'язань, передбачених Паризькою конвенцією. Крім того, виявлено недоліки білоруського законодавства, що нівелюють практичну доцільність звернення за судовим захистом у разі прямої дискредитації. Також запропоновано скорегувати поняття недобросовісної конкурениії з метою урахування в ньому можливості спричинення прямою дискредитацією одночасно $i$ збитків, $і$ шкоди діловій репутащії. Визнано доцільним доповнити згадану Постанову положеннями, що стосуються спещифіки захисту ділової репутації суб'єктів господарювання у разі порушення изого блага актом недобросовісної конкуренції.

Ключові слова: ділова репутація; дискредитація; конкурент; недобросовісна конкуренція; наклеп.

Problem setting. Business reputation is one of the main prerequisites for successful commercial activity, which necessitates not only its formation and strengthening, but also its effective legal protection from the activities leading to its disruption. The latter may be the result of various actions, including unfair competition through the dissemination of the discrediting information (hereinafter direct discrediting). For the time being the Belarusian legal regulation in this sphere includes both the provisions of its certain treaties ${ }^{1}$ and legal acts and is not only quite complex but has some gaps and other flaws to be identified and addressed.

Analysis of recent research and publications. The issues of the domestic legal protection against discrediting in the context of unfair competition are mainly covered in the papers dedicated to counteraction to unfair competition in general

\footnotetext{
${ }^{1}$ One of them is the Paris Convention for the Protection of Industrial Property of 1883 (hereinafter the PC) [1]. Since the PC has universal nature its provisions are of the greatest interest.
} 
[2-4]. Only few articles are specifically dedicated to the mentioned topic [5]. Meanwhile, none of the scientific works provides comprehensive analyses of the relevant provisions of the PC and of all the available civil law remedies in case of direct discrediting.

Statement of the article objective. The objective of the article is to identify the theoretical and practical problems of civil law protection against direct discrediting in the Republic of Belarus and to formulate some proposals for their resolution.

Presentation of the main body of the article. Article 1 (2) of the PC provides that the repression of unfair competition constitutes the object of the protection of industrial property. According to Article 10bis (1) of the PC the countries of the Union ${ }^{1}$ are bound to assure to nationals of such countries effective protection against unfair competition2. Moreover, pursuant to Article 10ter (1) of the PC the mentioned countries undertake to assure to nationals of the other countries of the Union appropriate legal remedies effectively to repress all the acts referred to in Article 9, 10, and 10bis. By virtue of Article 3 of the PC this protection shall also embrace nationals of countries outside the Union who are domiciled or who have real and effective industrial or commercial establishments in the territory of one of the countries of the Union.

As we can see the PC does not provide the detail regulation of the issues of protection against unfair competition. C. Wadlow rightly points out that while a civil action for an injunction is perhaps the most obvious and common means of enforcement, its availability is not the only way in which a member state of the PC may comply with the obligation to prohibit or repress unfair competition effectively. [6, p. 59]. Thus, the States Parties to the PC can provide any type of protection against unfair competition, including criminal and administrative ones; the issue of sanctions for its carrying out is also left to their discretion.

According to Article 10bis (3) (ii) of the PC false allegations in the course of trade of such a nature as to discredit the establishment, the goods, or the industrial or commercial activities, of a competitor shall be prohibited. The analysis of this and some other mentioned provisions of the PC allows making the following conclusions:

1) Article 10bis (3) (ii) of the PC is restricted to factual allegations; allegations or mere statements of value of opinions are not encompassed [7, p. 26] as they cannot be assessed from the point of their correspondence to reality;

2) Article 10bis (3) (ii) of the PC covers only false, e.g. objectively untrue allegations. The awareness of the wrongdoer of such a character of his or her statements is irrelevant. It has been left to the domestic legislation or case law of each country to decide whether, and under what circumstances, discrediting allegations which are not strictly untrue may also constitute acts of unfair competition $[8$, p. 145];

\footnotetext{
${ }^{1}$ I.e. the Union for the protection of industrial property, comprising all the countries to which the PC applies (Art. 1 (1) of the PC).

${ }^{2}$ The latter is defined through the notion of an act of unfair competition and a non-exhaustive list of examples of such acts (Art. 10bis (2), 3)) of the PC).
} 
3) all possible ways (on radio, television, Internet etc.) and methods (making presentation, advertising, distributing materials etc.) of making false allegations are covered;

4) it is not necessary for the allegations to be disseminated to an indefinite range of persons;

5) false allegations should be made in the course of trade. Any merely private social or political behavior does not fall within the scope of the provision of Article 10bis of the PC [8, p. 21];

6) the subject matter of the attack includes only the establishment, the goods and the industrial or commercial activities of a competitor [9, p. 46]. Thus, "discrediting acts ... focus on allegations concerning certain characteristics of products or services, as well as sales conditions" [10, p. 70];

7 ) it is in the very nature of discrediting to be directed against a particular businessman or a particular category of businessmen [10, p. 45]. They may not be directly mentioned in the allegations, but shall be identified. Article 10bis (3) (ii) of the PC requires certain competitive relations between the wrongdoer and the victim of discrediting, but it provides no definition of competitor or competition;

8) neither wrongdoer's motivation nor actual or potential damage are required for being considered as unfair competition under Article 10bis (3) (ii) of the PC. This provision "was intended to catch all disparaging statements about a competitor, which were contrary to truth, regardless of ... why they came to be made" [6, p. 64].

G. Schricker notes that according to the dominating, but not undisputed opinion of legal literature, Article 10bis of the PC is a self-executing provision (for the Member States where international conventions are applicable without having to be transferred into national legislation repeating their contents for domestic use) directly granting a minimal standard of protection against unfair competition [11, p. 133]. As the majority of scholars, including, G.H.C. Bodenhausen [8, p. 143], C. Wadlow [6, p. 52] and F. Henning-Bodewig [10, p. 54], we believe that the PC does not oblige its Member States to grant it to its own nationals, thus allowing their discrimination. The most persuading argument in favor of it is that as a rule states enter into international conventions primarily to protect their interests including those of their nationals - abroad (except for conventions on human rights); in so far as states wish to protect their own nationals at home, the normal and appropriate route is by domestic legislation [6, p. 52].

According to Article 1029 (2) of the Civil Code of the Republic of Belarus of December 7, 1998 (hereinafter - the CC) [12] false allegations in the course of entrepreneurial activity, capable to discredit a legal entity, an entrepreneur, goods, works, services or entrepreneurial activity of a competitor are deemed to be unfair competition. Article 25 of the Law of the Republic of Belarus of December 12, 2013 "On Counteraction to Monopolistic Activity and Promotion of Competition" (hereinafter - the Competition Law) [13] details the mentioned provisions of the $\mathrm{CC}$, providing that unfair competition through discrediting, that is, the dissemination of false, inaccurate or distorted information by an economic 
entity, including in relation to: the quality and consumer properties of the goods offered for sale by a competitor, the purpose of such goods, methods and conditions of their manufacture (production) or use, as well as the results expected from the use of such goods, their suitability for certain purposes; the quantity of goods offered for sale by a competitor, the availability of such goods on the market, the possibility of purchasing them under certain conditions, the actual volume of demand for such goods; the conditions under which the competitor offers the goods for sale, in particular the price (tariff), is prohibited.

It is necessary to pay attention to the notion of unfair competition ${ }^{1}$ provided in para. 10 of Article 1 of the Competition Law. In our opinion, it relates to the actions specified in Article 25-30 of the Competition $\mathrm{Law}^{2}$ as general with the particular, therefore, the relevant provisions should be applied (and are in fact applied) in practice cumulatively ${ }^{3}$. Otherwise it would be impossible to identify the sphere in which unfair competition is possible, the subjects whose actions can be recognized as unfair competition etc.

As we can see, the Belarusian legislation allows recognizing as unfair competition a broader range of actions compared to the one provided in the PC, which is allowed by this Convention.

It is worth to note that the persons aggrieved by unfair competition are entitled with the right to resort to administrative or judicial protection. Since their most complete restoration is realized due to protection in court, in particular, by recovering of damages and (or) moral harm, it deserves special attention.

Judicial protection against direct discrediting is carried out by the economic courts of the Republic of Belarus (Article 41 of the Economic Procedural Code of the Republic of Belarus of December 15, 1998 [16]). In some practice-oriented publications [17] it is stated that the consideration of unfair competition cases is the prerogative of the Intellectual Property Board of the Supreme Court of the Republic of Belarus, which is not quite accurate. By virtue of part 2 of Article 45 of the Civil Procedural Code of the Republic of Belarus of January 11, 1999, the Supreme Court of the Republic of Belarus in its first instance considers the disputes arising from the application of legislation regulating property and personal nonproperty relations arising in connection with the creation, legal protection and use of intellectual property [18]. Direct discrediting does not fall under the competence of this Court. As it is rightly pointed out in the literature, the CC does not attribute

\footnotetext{
${ }^{1}$ Pursuant to it unfair competition - any actions of an economic entity or several economic entities aimed at obtaining advantages (benefits) in entrepreneurial activity contradicting this Law, other legislative acts and acts of antimonopoly legislation or requirements of good faith and reasonableness and can cause or have caused losses to competitors or can cause or have caused damage to their business reputation.

${ }^{2}$ In literature they are called unfair competition forms [14, p. 71] or types of unfair competitive actions [15].

${ }^{3}$ This means, in particular, that the actions specified in Art. 25 of the Competition Law may be recognized as unfair competition only if they can cause real or potential losses to competitors or real or potential damage to their business reputation.
} 
unfair competition to intellectual property [19]. The inclusion of chapter 68 "Unfair competition" in section V of the CC is artificial, since the subject-matter of legal regulation of its norms is not exclusive rights to the results of intellectual activity and the means of individualization of civil turnover participants, but the competitive relations of business entities, and is explained only by the literal adherence to the PC without taking into account those historical realities under which unfair competition was considered as an industrial property category [1].

From Article 1029 (2) of the CC, Article 25 and para. 10 of Article 1 of the Competition Law follows that for judicial protection against direct discrediting, besides the existence or lack of competitive relationship between the plaintiff and the defendant, the following circumstances should be examined in their entirety: the fact of dissemination (provision to certain persons) of the information concerning the goods, business activity or the injured competitor; the fact of inconsistency of the disseminated or provided information with reality (its falsity, inaccuracy, distortion); the fact of losses or damage to a competitor's business reputation or the possibility of such consequences for him or her in the future. In the absence of any of them the claim for protection against direct discrediting may not be satisfied.

The peculiarity of direct discrediting, unlike other forms of unfair competition, is that it is usually connected with attacks on business reputation. The latter is an assessment of a participant of an entrepreneurial relationship by its other participants, the diminishment (discrediting) of which can negatively affect carrying out such activity. Dissemination of false information about non-originality, low technical level, fragility of the products produced by a competitor, the use of prohibited or undesirable components in their manufacture, violation of technology, etc. diminishes business reputation of the plaintiff, on whose goods or entrepreneurial activities the competitor disseminated such information. Depending on the content of the disseminated information, the aggrieved person may acquire, in the eyes of other persons, including consumers, the characteristics of an unfair, incompetent, unreliable (non-performing his or her obligations), violating the law, not a credible market participant. Diminishment of business reputation may entail erosion of the customer base, loss of business partners and investors, a tangible flight of personnel, a decrease in revenues and profitability, and as a result, the need for significant costs for new advertising, search for new distribution channels, recruitment, etc. Thus, harm to business reputation as to an intangible good may also entail property losses.

In the Republic of Belarus there are no special rules on civil-law protection against direct discrediting, entailing harm to his or her business reputation, including the ones clarifying through judicial interpretation the provisions contained in the $\mathrm{CC}$ and the Competition Law on direct discrediting. Therefore, it is possible to apply Article 153 of the CC and Resolution of the Plenum of the Supreme Economic Court of the Republic of Belarus of April 26, 2005 № 16 "On certain issues of judicial application of legislation considering cases of protection of business reputation" (hereinafter - the Resolution) by analogy and in coinciding regulation [20]. 
In accordance with part 1 of para. 2 of the Resolution, the dissemination of the information not corresponding to reality is its communication to an indefinite circle of persons. Possible ways of dissemination of the relevant information are: publication in print media, in radio-, television- and video programs, placement on the global computer network Internet as well as demonstration on posters, stands, light boards. The dissemination "in other forms" is allowed. We believe, it shall, cover, for example, public addresses to a large audience (if it is proved) etc.

At the same time, direct discrediting is in fact often associated with, on the contrary, targeted, "point-like" distribution of false, inaccurate, distorted information about a competitor, casting a shadow on his business reputation, for example, by sending letters to a competitor's counterparties, including via email or using cellular mobile telecommunications. This is taken into account in para. 2) of Part 2 of Article 1029 of the CC, which, in contrast to Article 25 of the Competition Law, does not use the term "dissemination" (its wording almost completely reproduces the relevant provision of the PC). The information about various aspects of entrepreneurs' market activity affects their economic situation not only when it becomes available to wide groups of recipients (for example, through the mass media), but also when it is sent to a narrower circle of already defined recipients [21, p. 563]. Provision of false, inaccurate, distorted information to several or even one person, for example, to a competitor's serious partner, may be sufficient to damage competitor's business reputation. Thus, protection against direct discrediting should not be blocked in such situations and the relevant gap in the legal regulation at issue needs to be eliminated.

Communication of information can be carried out through advertising. In accordance with subpara. 6 of Article 2 of the Law of the Republic of Belarus of May 10, 2007 "On Advertising" (hereinafter - the Advertising Law) not only goods, but also an organization or a citizen, including an entrepreneur, their rights and interests or obligations protected by law, means of individualization of participants of civil turnover, goods, results of intellectual activities as well as contests, lotteries, games, other gaming, advertising and other events, betting, social phenomena (events), etc. can be the object of advertising [22]. Advertising information may be distributed "in any form by any means" (subpara. 9 of Article 2 of the Advertising Law). However, there are certain restrictions for the use of specific methods of dissemination of advertising (Article 12 (1) of the Advertising Law). An inherent characteristic of advertising is that the information contained in it always addressed to an indefinite range of persons.

Para. 11 of the Resolution includes the character of not corresponding to reality information (denigrating a legal entity or an entrepreneur in the field of business activity) in the subject-matter of proof in cases on protection of business reputation. This is also relevant for the protection against direct discrediting infringing on competitor's business reputation. From the Resolution it follows that not denigrating false, inaccurate or distorted information cannot affect business reputation. On the other hand, if such information is spread as a result of direct discrediting, according to the abovementioned notion of unfair competition 
competitor's business reputation has been harmed or may have been harmed. Denigrating information is information of reprehensible character. Part 1 of para. 3 of the Resolution gives some examples of such information - about violation of the legislation in force, bad faith in the course of business, violation of business ethics. To get protection against direct discrediting, it seems sufficient for business reputation to be questioned, diminished to a certain extent. The degree of negativity of the disseminated information cannot be taken into account when deciding whether to apply such a remedy as refutation of the disseminated information and actions constituting unfair competition.

The information, discrediting business reputation of a legal entity in the business sphere, also includes not corresponding to reality data about the activities of its separate structural unit, its manager, other employees in the performance of their labor functions and (or) official powers (part 2 of para. 4, part 2 of para. 3 of the Resolution № 16). The Resolution does not take into account the "employer" legal capacity of entrepreneurs. However, we believe that the courts should protect them from direct discrediting if false, denigrating information is disseminated in relation to entrepreneurs' employees in connection with the performance of their staff responsibilities.

Dissemination of not corresponding to reality denigrating information for the purpose of protection against unfair competition, including in the form of direct discrediting, must be carried out for gaining an advantage in business activity or lead to certain advantages for the offending competitor. The latter can be illustrated on the following case. An entrepreneur A. distributed false information about counterfeiting of the medical products supplied to the commodity market of the Republic of Belarus by his competitor. A. left critical reviews in the retailers' books of complaints and repeatedly addressed to law enforcement and other bodies to make them prove the legitimacy of trade operations carried out by the competitor. As a result the aggrieved competitor's product was withdrawn from the turnover, his contractual relations with many retailers were suspended and consumer confidence was undermined. The content of the disseminated information was refuted by the results of the aggrieved person's own inspection and the manufacturer's expertise. According to the Supreme Court of the Republic of Belarus, in this situation gaining an advantage in business activity was achieved by reducing the sales of competitor's goods, in respect of which false, denigrating information was disseminated [23].

The corresponding to reality information about deficiencies in entrepreneur's or a legal entity's entrepreneurial activity or the information having the character of a value judgment or opinion which cannot be checked for the correspondence to reality, is not denigrating (part 3 of para. 3 of Resolution).

At the same time, it bears noting that the object of direct discrediting is wider than the one of the relevant offense in case of protection of business reputation in common civil law sense. Moreover, the content of particular not corresponding to reality disseminated information concerning competitor, his or her goods or entrepreneurial activity can be different, in some cases - not denigrating, for 
example, the dissemination of false information that a competitor's product does not perform these or other functions, or that the competitor is insolvent. This does not exclude the possibility of protection against direct discrediting, if a business entity has suffered or may suffer losses and the information was disseminated for gaining advantages in business activities. It is necessary that the losses be in causal connection with the dissemination of false information. We propose to consider the existence of losses (threat of losses) as an objective criterion of direct discrediting. In particular, when the dissemination of false information causes (can cause) damages, it does discredit, even if the information is not denigrating. Thus, direct discrediting is not limited solely to the actual or potential attack on business reputation with the "classic" structure of the offense (dissemination of information, its inconsistency with reality and denigrating character).

According to Article 26 (5) of the Advertising Law inappropriate advertising is not allowed. The Law in subpara. 5 of Article 2 and Article 26 enumerates specific types of inappropriate advertising: unfair, inaccurate, unethical, hidden, as well as other. The analysis of Article 26 of the Advertising Law providing a list of information constituting each type of improper advertising, allows making the conclusion that certain elements of unfair competition in the form of direct discrediting (as well as in other forms) can manifest exclusively in unethical advertising.

In accordance with subpara. 5 of para. 3 of Article 26 of the Advertising Law unethical advertising is, inter alia, advertising which denigrates any organization or citizen, any activity, profession, product ${ }^{1}$. In the context of unfair competition in the form of direct discrediting we can only talk about the dissemination of denigrating information through advertising. However, if unethical advertising contains false, inaccurate or distorting information denigrating competitor, his or her business activities or goods, focuses on obtaining advantages in business activities and its content was determined by a competitor, it shall be recognized as an act of unfair competition and result in (at the request of the plaintiff) protection precisely in connection with the violation of competition rules.

It bears noting, that the Russian legal science pays great attention to the research of the correlation of inappropriate advertising and unfair competition in order to answer the questions whether any improper advertising is simultaneously an act of unfair competition and how legislation on advertising and on competition relate to each other [24-27]. It is not pertinent for the Belarusian science since the specificity of the Belarusian Advertising Law is that it does not bind advertising and competition, including unfair one, in its rules. By the way, in the Advertising Law the word "competition" is not even mentioned. At the same time, it is clear from the content of this Law that one of its goals is the development of competition and the prevention of unfair competition. Advertising has its positive effect on the development of competition only if during its production and (or) distribution there

\footnotetext{
${ }^{1}$ For the qualification of advertising as unethical it is enough for the information to be denigrating without taking into account whether it corresponds to reality or is unreliable.
} 
were no violations of law. The Advertising Law provides an opportunity for plaintiffs to act in accordance with the specific circumstances of the case and to file lawsuits for the violation of the requirements set forth exclusively for advertising and its dissemination, and if other necessary conditions are met, - other lawsuits, including those related to protection against unfair competition. It seems that for that very reason, Article 31 (2) of the Advertising Law does not specify the claims that may be presented in court by the persons whose rights and legitimate interests are violated as a result of the production and (or) placement (distribution) of inappropriate advertising, including unethical one. Rather it speaks in general terms about lawsuits, naming only one of them - a lawsuit for material compensation of moral harm ${ }^{1}$. In this connection, due to the discrepancy between the elements of violations in the field of advertising and competition, the establishment of the correlation between improper advertising and unfair competition given the Belarusian legal realities seems to be devoid of practical meaning.

In accordance with part 2 of para. 9 of the Resolution the claimant is obliged to prove only the fact of the dissemination of the information discrediting his business reputation in the field of entrepreneurial activity. The burden of proof of the fact that the disseminated information corresponds to reality is levied on the defendant (part 3 of para. 9 of the Resolution), but the claimant has the right to provide evidence of its discrepancy with the reality and its negative impact on his business reputation in the business sphere (part 2 of para. 9 of Resolution).

The issue of specific remedies to be used for protection against acts of unfair competition, including direct discrediting, is solved in Chapter 68 of the CC given their consequences (damaging business reputation and causing losses). According to Article 1030 (1) of the CC, the person carrying out unfair competition is obliged to cease unlawful actions and publish a refutation of the disseminated information and actions constituting the content of unfair competition. Article 1030 (2) of the $\mathrm{CC}$ entitles the person aggrieved by unfair competition with the right to demand that the violator-competitor compensate the losses caused.

It is worthy to note that filing of a claim for refutation of false or inaccurate or distorted information denigrating the aggrieved competitor, his business activities or goods, works, services, does not exclude, as it follows from Article 153 (5), (7)) of the CC, filing additionally (simultaniously) claims for damages. According to our previously expressed opinion, the dissemination of false information may be qualified as direct discrediting even when the information is not denigrating but it causes or may cause losses. In this regard, we believe that it is necessary to replace the words "can cause or have caused damage to their business reputation" used in the unfair competition notion with the words "and / or can cause or have caused damage to their business reputation".

Pursuant to part 1 of para. 2 of Article 14 of the $\mathrm{CC}$ the losses include the expenses which the person whose right has been violated made or must make in

${ }^{1}$ The Advertising Law presumes the existence of moral harm in the commission of unlawful acts envisaged by it. 
order to restore the violated right, loss or damage of his property (real damage) as well as the revenues not received which this person would have received under ordinary conditions of civil turnover if his right had not been violated (lost profit). Thus, the CC provides for the principle of full compensation of losses. According to O. A. Gorodov, who analyzed the relevant provision of the Russian Civil Code, the composition of real damage includes the expenses actually incurred by the creditor, as well as the expenses that he or she has to incur to restore the violated right. $\mathrm{He}$ believes that the loss or damage to property in the composition of real damage due to unfair competitive actions is unlikely. The expenses that the person has to incur to restore the violated right as well as the lost profit this author calls "potential losses" [28, p. 22].

In cases where an act of unfair competition is assessed by a creditor as capable of causing him losses (but not actually having caused losses), the aggrieved competitor has to prove the amount of this particular part of real damage and the amount of lost profit which is not an easy matter. It is also not simple to prove the fact of "potential" losses. For example, in case of a potential counterparty's refusal to cooperate with the claimant, recovering the losses in the form of lost profit necessitates proving that the reason for such a refusal was exactly the fact of dissemination of false, inaccurate, distorted information about the plaintiff by the unfair competitor. For the time being the CC does not allow the court to recover the losses caused if their amount has not been proved, which in practice means "limited" protection, since in this case there is no restoration of the situation existed prior to the violation of the right. In this regard, the experience of the Russian Federation, which legislation establishes the rules prohibiting the court to refuse to recover losses solely on the basis that it is impossible to determine their exact amount with a reasonable degree of certainty seems positive. In this case the amount of the losses to be recovered shall be determined by the court taking into account all the circumstances of the case based on the principles of fairness and proportionality of the liability to the violation of the obligation (Article 393 (5) of the Civil Code of the Russian Federation (Part 1) of 30 November, 1994) [29].

The list of civil law remedies against unfair competition, highlighted by the legislator in Article 1030 of the CC (refutation, compensation of losses) is narrower, but consistent with Article 11 of the CC, containing the list of civil law remedies, including suppression of the actions violating a right or creating a threat to its violation (para. 3), restoration of the situation existed before the violation of the right (para. 2). This raises the question of the possibility of using other civil law remedies, provided in Article 11 of the $\mathrm{CC}$, in particular, compensation for moral harm. The Competition Law does not provide for such an opportunity for the aggrieved competitors, regardless of whose business reputation (legal entity's or entrepreneur's one) is impaired or will be impaired as a result of direct discrediting. The non-recognition of legal entities' right to compensation for such harm in connection with the impairment of their business reputation follows from the interpretation of the provisions of Part 1 of Article 152, Article 153 (7) of the CC, in 
which the right to claim the specified compensation is provided for citizens only. In part 1 of para. 12 of the Resolution it is clarified that an entrepreneur, about whose entrepreneurial and other economic activities the information not corresponding to reality and damaging his or her business reputation is disseminated, has the right to claim compensation for moral harm. Pursuant to part 1 of para. 13 of the Resolution, moral harm is understood as moral or physical suffering of a citizen who is an entrepreneur caused by the actions encroaching on his business reputation and violating his rights and legitimate interests in business and other economic activities' sphere.

Having in common, that both direct discrediting and damaging business reputation of an entrepreneur, for example, by non-competitor, have negative effect primarily on the rights in the field of entrepreneurial activity, the mentioned Resolution provides for compensation of moral harm in case of filing a lawsuit for the protection of business reputation or submission of an application for the recognition of the information denigrating business reputation as non-corresponding to reality. Thus, compensation for moral harm to an entrepreneur in these cases represents a special rule in relation to the general rule on the citizens' right to such compensation. However, is it possible to interpret this rule expansively, applying it for the protection against unfair competition in the form of direct discrediting? Protection against direct discrediting has certain specifics. Claiming compensation for moral harm or recovering damages in case of unfair competition requires establishing the fact of the relevant antimonopoly legislation violation by the antimonopoly authority or the court, but if such a fact is established, further differences in the methods of protection of business reputation of an entrepreneur are not justified. As it follows from Article 22 (2) of the CC, the essence of the legal relationship in this case determines the non-application of the $\mathrm{CC}$ rules, regulating the activities of commercial organizations, to entrepreneurial activity of entrepreneurs. In addition, it is clear that, with such a concurrent element of the offences as damage to business reputation, there should not be less opportunity for an entrepreneur for its protection in a case of unfair competition, especially since the remedies provided for by the Resolution can be used as alternatives. However, legal uncertainty remains, which may lead to conflicting decisions in the law enforcement process. We believe that this issue requires legal regulation, taking into account the importance of restoring the violated right to the business reputation of an entrepreneur in full in the framework of protection against unfair competition ${ }^{1}$.

\footnotetext{
${ }^{1}$ In the Belarusian scientific literature this issue is not addressed. In the Russian legal science different opinions can be found, mainly in support of the possibility of a claim for compensation for nonpecuniary damage for an entrepreneur, whose business reputation has suffered from an act of unfair competition. In particular, K.Ju. Tot`ev notes: “...entrepreneurs are entitled to claim compensation of losses and non-pecuniary damage caused by the dissemination of the discrediting business reputation information in the course of unfair competition..." [30]. The same position is held by V.I. Yeremenko [31] At the same time, the Russian science has long paid great attention to the development of the concept of intangible (reputational) harm, which in its legal content is similar to the concept of moral harm, but used in commercial turnover in relation to legal entities.
} 
It shall be emphasized that the claimant in the lawsuit concerning unfair competition must be a competitor or competitors. This also applies to the cases where the court is requested to refute the disseminated information and actions that constitute the content of unfair competition. Other persons involved in the dissemination of information (legal entity entrusted with the editorial functions of the mass media, the owner of the Internet resource, advertising distributors, etc.) may act as co-defendants or third parties. In the absence of evidence of the dissemination of false, denigrating information by a competitor or in the absence of information about the person who disseminated such information, judicial protection of the rights of the aggrieved economic entity is possible only within the framework of the lawsuit for the protection of business reputation or application for the recognition of the information denigrating business reputation as non-corresponding to reality.

In connection with the use of such a remedy as a refutation, the following rules should be taken into account:

upon the presentation of a request for the publication of a refutation, its text must be submitted by the plaintiff to the court (part 1 of para. 10 of the Resolution);

the information discrediting the business reputation of the plaintiff should be refuted in a way that is closest to the method of their dissemination (part 2 of paragraph 11 of the Resolution). False, inaccurate, distorted information infringing the competitor's business reputation and disseminated in the mass media should be refuted in the same media (part 1 of para. 2, para. 7 of Article 153 of the CC). Article 43 of the Law of the Republic of Belarus of July 17, 2008 "On Mass Media" (hereinafter - the Mass Media Law) [32] regulates in detail the procedure for refuting disseminated information if this information does not correspond to reality and discredits business reputation. The procedure for refutation in other cases is established by the court (part 3 of para. 2 of Article 153 of the CC);

the claimant has the right to file a demand for refutation without prior compliance with the pre-trial procedure for making such a claim to the person who disseminated this information (part 1 of para. 4 of the Resolution);

the obligation to refute false information, denigrating business reputation of a competitor may be assigned to a legal entity serving as the editorial staff of the mass media, or to the owner of an Internet resource (part 1, 2 of para. 1 of Article 42 of the Mass Media Law).

Conclusions. The Republic of Belarus fully abides by its international obligations in the field of protection against unfair competition through discrediting undertaken under the PC. However, the most effective, adequate protection against this form of unfair competition necessitates the improvement of the domestic legislation. The obstacles to solving this problem are: the lack of the norm allowing the court to recover damages if their amount is not proved as well as the norms entitling entrepreneurs with the right to compensation for moral harm if their business reputation is or can be damaged by direct discrediting; the denial of legal entities' right to compensation for non-pecuniary (reputational) 
damage. These gaps in the Belarusian legislation negate the feasibility of recourse for judicial protection.

Since direct discrediting may negatively result in both losses and damage to business reputation, it is necessary to appropriately correct the unfair competition notion provided in the Competition Law.

Resolution needs to be supplemented with the provisions concerning the specifics of protecting business reputation of economic entities in case of violation of this good by an act of unfair competition.

\section{References}

1. Paris Convention for the Protection of Industrial Property of 1883. URL: https://www.wipo. int/treaties/en/ip/paris/.

2. Losev, S.S. Nedobrosovestnaja konkurencija. URL: Konsul'tantPljus. Belarus' [in Russian].

3. Losev, S.S. Institut zashhity ot nedobrosovestnoj konkurencii: novoe v zakonodatel'stve. URL: Konsul'tantPljus. Belarus' [in Russian].

4. Maskaeva, N.G. (2016). Nedobrosovestnaja konkurencija v mezhdunarodnom chastnom prave. Minsk: Biznesofset [in Russian].

5. Rachkovskij, V.V. Protivodejstvie nedobrosovestnoj konkurencii i zashhita delovoj reputacii. URL: http://intelpro.by/publikacii/nedobrosovestnaya-konkurenciya/ [in Russian].

6. Wadlow, C. (2011). The Law of Passing-Off: Unfair Competition by Misrepresentation. London: Sweet \& Maxwell.

7. Henning-Bodewig, F., Augenhofer, S., Auteri, P., Bacher, G. et al. (2013). International handbook on unfair competition. München: C. H. Beck.

8. Bodenhausen, G.H.C. (1968). Guide to the Application of the PC for the Protection of Industrial Property as Revised at Stockholm in 1967. Geneva: BIRPI.

9. Protection Against Unfair Competition Analysis of the Present World Situation: WIPO Publication No. 725(E). (1995). Geneva: WIPO.

10. Hilty, R.M., Henning-Bodewig, F. (2007). Law against unfair competition. Towards a new paradigm in Europe. Berlin: Springer.

11. Schricker, G. (1995). International aspects of the law of unfair competition. International harmonization of competition law. Chia-Jui Cheng, S.-Liu Lawrence and Ching-Kang Wang (Eds.). Dordrecht; Boston: M. Nijhoff, 129-139.

12. Grazhdanskij kodeks Respubliki Belarus' ot 07.12.1998 g. № 218-Z. URL: http://pravo.by/ document/?guid=3871\&p0=hk9800218.

13. O protivodejstvii monopolisticheskoj dejatel'nosti i razvitii konkurencii: Zakon Respubliki Belarus' ot 12.12.2013 g. № 94-Z. (v red. Zakona ot 08.01.2019 g. № 98-Z). URL: http://pravo.by/ document/?guid $=3871 \& \mathrm{p} 0=\mathrm{H} 11300094$.

14. Tot'ev, K.Ju. (2000). Konkurentnoe pravo. Moscow: Kontrakt; Infra-M [in Russian].

15. Eremenko, V.I. Osobennosti presechenija nedobrosovestnoj konkurencii v Rossijskoj Federacii. URL: Konsul'tantPljus. Rossija [in Russian].

16. Hozjajstvennyj processual'nyj kodeks Respubliki Belarus' ot 15.12.1998 g. № 219-Z. (1998). URL: http://pravo.by/document/?guid=3871\&p0=HK9800219 [in Russian].

17. Rachkovskij, V.V. (2018). Vybiraem instanciju dlja obzhalovanija nedobrosovestnoj konkurencii. Promyshlenno-torgovoe pravo, 6, 65-67 [in Russian].

18. Grazhdanskij processual'nyj kodeks Respubliki Belarus’ ot 11.01.1999 g. № 238-Z. (1999). URL: http://pravo.by/document/?guid $=3871 \& \mathrm{p} 0=\mathrm{hk} 9900238$.

19. Popova, I.V., Svadkovskaja, E.A., Chigir,V.F. Postatejnyj kommentarij k Grazhdanskomu kodeksu Respubliki Belarus'. Razdel V. Iskljuchitel'nye prava na rezul'taty intellektual'noj 
dejatel'nosti (intellektual'naja sobstvennost') (stat'i 979-1030). URL: Konsul'tantPljus. Belarus' [in Russian].

20. O nekotoryh voprosah primenenija sudami zakonodatel'stva pri rassmotrenii del o zashhite delovoj reputacii: postanovlenie Plenuma Vysshego Hozjajstvennogo Suda Respubliki Belarus'. URL: https://etalonline.by/document/?regnum=x20500016\&q_id=806928.

21. Zdyb, M., Sieradzka, M., Arkadiusz Michalak, A., Mioduszewski, M. et al. (2016). Ustawa o zwalczaniu nieuczciwej konkurencji. Komentarz. Warszawa: Wolters Kluwer.

22. O reklame: Zakon Respubliki Belarus' ot 10.05.2007 g. № 225-Z. (2007). URL: https:// etalonline.by/document/?regnum $=\mathrm{h} 10700225 \& \mathrm{q}$ id $=806970$.

23. Reshenie Verhovnogo Suda Respubliki Belarus' ot 16.06.2017 g., sudebnoe delo 4-15/2017. N.P.

24. Bolotnov, I.A. (2009). Nedobrosovestnaja konkurencija i nenadlezhashhaja reklama. Korporationyj yurist, 5, 56-59 [in Russian].

25. Drogova, E.V. (2013). Sootnoshenie nedobrosovestnoj konkurencii i nenadlezhashhej reklamy. Pravoporjadok: istorija, teorija, praktika, 1, 62-65 [in Russian].

26. Kulikova, Ju.S. (2003). Nenadlezhashhaja reklama kak forma nedobrosovestnoj konkurencii. Extended abstract of candidate's thesis. Moscow [in Russian].

27. Tot'ev, K.Ju. (2009). Nenadlezhashhaja reklama i nedobrosovestnaja konkurencija: kollizija sostavov i sposoby ee ustranenija. Zakony Rossii: opyt, analiz, praktika, 10, 10-18 [in Russian].

28. Gorodov, O.A. (2009). Ponjatie i obshhaja harakteristika nedobrosovestnoj konkurencii. Sovremennaja konkurencija, 6, 15-25 [in Russian].

29. Grazhdanskij kodeks Rossijskoj Federacii (Chast' pervaja) ot 30 noyabrya 1994 g. № 51-FZ. (1994). URL: http://www.consultant.ru/document/cons_doc_LAW_5142/.

30. Tot`ev, K.Ju. (2007). Nedobrosovestnaja konkurencija vo Francii i Rossii. Zakonodatel'stvo $i$ jekonomika, 2, 66-72 [in Russian].

31. Eremenko, V.I. (2000). Osobennosti presechenija nedobrosovestnoj konkurencii v Rossijskoj Federacii. Advokat, 7, 7-24. URL: http://base.garant.ru/5333532/ [in Russian].

32. O sredstvah massovoj informacii: Zakon Respubliki Belarus' ot 17.07.2008 g. № 427-Z. (2008). URL: http://pravo.by/document/?guid=3871\&p0=H10800427.

Денисенко М. А., кандидат юридических наук, доцент, доцент кафедры международного частного и европейского права, Белорусский государственный университет, Республика Беларусь, г. Минск.

e-mail : marina-denisenko@tut.by

Maскаева $\boldsymbol{H}$. $\boldsymbol{\Gamma}$, кандидат юридических наук, доцент, доцент кафедры международного частного и европейского права, Белорусский государственный университет, Республика Беларусь, г. Минск.

e-mail : maskayeva_nat@mail.ru

Гражданско-правовая защита от прямой дискредитации: Парижская конвенция и белорусское законодательство

В статье анализируются положения Парижской конвенции об охране промышленной собственности 1883 г. и законодательства Республики Беларусь, касающиеся недобросовестной конкуренции путем прямой дискредитащии. Подробно рассмотрены меры гражданско-правовой защиты и ответственности, которые могут быть применены в случае совершения указанного правонарушения. Сделан вывод о полном соблюдении Республикой Беларусь соответствующих международных обязательств, предусмотренных Парижской конвенщией, наличии в белорусском законодательстве ряда пробелов, которые нивелируют практическую челесообразность обращения за судебной защитой в случае прямой дискредитащии, а также о необходимости внесения в него некоторых изменений. 
Ключевые слова: деловая репутация; дискредитация; конкурент; недобросовестная конкуренция; клевета.

Рекомендоване цитування: Denisenko M. A., Maskaeva N. G. Civil law protection from direct discrediting: the Paris Convention and the Belarusian Legisation. Проблеми законності. 2019. Вип. 146. С. 75-90. doi: https://doi.org/10.21564/2414-990x.146.179021.

Suggested Citation: Denisenko, M.A., Maskaeva, N.G. (2019). Civil law protection from direct discrediting: the Paris Convention and the Belarusian Legisation. Problemy zakonnosti - Problems of Legality, issue 146, 75-90. doi: https://doi.org/10.21564/2414-990x.146.179021.

Надійшла до редколегії 12.06.2019 p. 